\title{
EXPLORING THE ARCHITECTURAL DIMENSIONS OF VULNERABILITY: A CASE OF THE PARTICIPATORY UPGRADATION IN INFORMAL SETTLEMENT AT TALAIMARI, RAJSHAHI
}

\author{
Md. Shahriar Hossain* (ic) \\ Department of Building Engineering and Construction Management (BECM), Khulna University of Engineering \\ \& Technology, Bangladesh
}

Received: 13 February 2021

Accepted: 16 June 2021

\begin{abstract}
The informal settlers have been enduring a vast array of substandard, overcrowded, and hazardous living conditions. The main objective of this research is to provide some design guidelines for future generation expansion of the slum with minimum interventions of the slum dweller's way of life. The empirical information was obtained through field survey and interview program from 120 participants in a particular slum area located in the fourth largest city of Bangladesh namely, Rajshahi. For this research extensive level of field work has been performed for mapping the existing infrastructure and physical condition of the settlement. The findings reveal the household and housing characteristics, dynamic space sharing relationship among the households, indigenous house making techniques and development obstacles. Respecting the existing considerable disparity and variety of the settlement, the design guidelines and polices are provided on the basis of "minimum relocations, maximum retentions". The outcome of this research will help the authority to ensure tenure security of the slum dwellers through design justice.
\end{abstract}

Keywords: Design Interventions; Informal Settlement; Participatory Upgradation; Vulnerability.

\section{INTRODUCTION}

More than anything else, access to secure land is the thing that separates the poor from the non-poor in Asian cities (UN-Habitat, 2008). Shelter in a slum is affordable and appropriate for people on low and irregular incomes due to well-location in terms of urban jobs and livelihoods (Turok and Saladin, 2016). Of a population of nearly 163 million people in Bangladesh, it is estimated that 55.1\% live in slums (HHB, 2019). The number of poor migrant is rapidly growing every year because of the effects of climate change, river erosion or loss of livelihoods (WBB, 2019). The cities are so dominated by the poor that the urbanization process can be understood to some extent as the 'urbanization of poverty' (Bari and Efroymson, 2009; CPD, 2001). The drivers of urban pull factors (e.g. industrialization, economic growth) contribute to this process creating inequalities and different socio-spatial realities for urban poor in terms of residential and economic segregation based on income, and access to resources, urban services and facilities (Satterthwaite et al., 2009). The challenges experienced by communities living in slums, such as the threat of eviction and the lack of access to government services, require the collaboration of numerous stakeholders across the city (HHB, 2019). Informal settlements and urban poverty are not just a manifestation of a population explosion and demographic change, but an expression of failure of housing policies, laws and delivery systems, as well as of national development plans and urban policies (UN-Habitat, 2003).

In densely populated informal settlements, a high percentage of houses are in a structurally poor built condition with temporary or semi-permanent materials (LIUPCP, 2015). Subsidized housing is beyond cover for millions of low-income families, as a result of insufficient income and national and local housing policies that cannot cover urban poor (UN-Habitat, 2012a; Smets and Lindert, 2016; Ahmed, 2016). Poor and low-income people who no longer have access to affordable land of operation and approved housing are encouraged in informal settlements (Abebe, 2011). The contradictions between what is actually built and what people require causes lead to $62 \%$ of the population in urban areas living in slums (UN-Habitat, 2009). The initiatives of third world policymakers include, among others, affordable public housing, sites and services programs, slums and neighborhood upgrades, but none of these programs will meet housing needs on a wide scale (Abebe, 2011). The people reacted by creating self-planned settlements or informal settlements in response to this malfunctioned and inefficient land distribution system (Fekade, 2000). 
As African cities triple in size and South Asian cities more than double by 2050 are expected to raise the demand for housing exponentially (Asian Development Bank, 2011). If buildings corporations were selling formal houses at precisely the expense of constructing without benefit, accommodation for ordinary people would still be inaccessible (Collier et al., 2017). Slum upgrade projects are partnering with existing resources in informal settlements to improve access to utilities, provide affordable housing and ensure tenure security in the same land (in situ) as the inhabitants are currently located. Lack of security of land tenure remains a major constraint on poverty reduction. Regularization of land tenure allows communities in particular to invest safely in their properties. Improving the livelihood and working conditions refers to physical capital in the form of often large existing housing and "social capital" investments, in the form of community connections, local job opportunities and local service networks (Collier et al., 2017). Policymakers are expected to evaluate the necessary scope and design of the program cost efficiently to execute slum-upgrade projects. The role of tenants in improving service delivery may also require challenging policy decisions to be considered (Collier et al., 2017). Reforms to create laws that allow "incremental housing" strategies will make it easier for the private sector to provide housing at a dramatically low cost in many cities than otherwise possible. It only provides the parts of a house that owners are less able to construct themselves (such as foundations and roofing), allowing owners to invest in the completion of their houses when they make the money for this purpose (Wainer et al., 2016).

Community participation in the development of inner-city slums is a key component of any upgrade project, a diversity of interests among participants is a fundamental challenge which requires particular consideration of policy (Lemanski, 2008). A small but growing number of literatures shows that participation in planning and managing all development projects is indispensable through consultation with people (Sen, 1990; World Bank, 2001; Koenig, 2006; Arputham, 2008; Banks, 2008; Mitlin, 2008). Participation has a powerful influence on lives of people by strengthening their autocracy and regard for themselves (Abebe and Hesselberg, 2015). Koenig considers participation to be a mechanism against poverty. He believes that voicelessness and the absence of voices are important aspects of poverty. Participation assists community members to monitor and take responsibility for their own well-being.

This study offers knowledge on the urban informal settlement development process from the point of view of architectural design and community participation that have experienced participatory house design approach. Based on contextual data from interviews and discussions with focus groups, it reviews how the community people in a particular informal settlement are affected by the threat of natural disaster and going through the fear of eviction. The analysis reveals the physical forms, informal economy, complex relationship between the tenant and occupant, extent of community participation on designing their own future house and the differential ways are experienced by different households. It also ties between the desire of the inhabitants about their future house form and their present economic condition. This study shows a way how the authority can provide tenure ship to the inhabitants according to the basic needs and justice with the minimum relocations within the site.

\section{STUDY AREA AND CONTEXT}

\subsection{Introducing Rajshahi}

The analysis was carried out in Rajshahi, the fourth largest city of Bangladesh. Urban growth is primarily a result of rural-urban migration and massive numbers migrate to the city in order to prevent the complex impact of climate change on the environmentally vulnerable river delta (Afsar, 2000). The city of Rajshahi is situated on the Padma river (Ganges), northwest of Bangladesh, on the Indian-Bangladesh border. The Rajshahi district population is 2.2 million and around 800,000 people live in Rajshahi city (UPPR, 2012). The city is usually absent of industry and export markets, its economy being dependent on services offered to the tertiary education sector, including the University of Rajshahi, one of the country's largest public Universities, as well as many smaller public and private universities and colleges (Walters, 2018). In Bangladesh, Rajshahi is one of the four City corporations that administer the city, a government level subordinate only to the government of the country. The Rajshahi City Corporation (RCC), which works in the field of urban infrastructure, health, public utilities and public health, is responsible for the provision of day-to-day government services. Even though commitments are important, it does not have enough power to increase tax locally because finance at national government level is highly centralized, particularly for development programs (Huq, 2013).

Much like all cities in Bangladesh, a large proportion of the population of Rajshahi approximately 35\% is living in circumstances that match the United Nations interpretation of an urban slum (Islam et al., 2006). The following criteria are sometimes absent for these dwellings: 1) Sustainable permanent housing which protects from severe climate conditions; 2) adequate living space with not more than three people in the same room; 3) Quick access to clean water at an affordable cost in adequate quantity; 4) Access to effective sanitation, shared 
by a reasonable number of people in the form of private and public sanitation; 5) Tenure security that prevents enforced eviction (UN Habitat, 2006). The studies and interviews of the case study site suits this concept of a slum with unsafe and overpopulated housing, poor ventilation, unsafe heat and rain safety, poor drainage and sanitation and insufficient access to political power.

\subsection{Study Area}

The site was inhabited by homeless people after the original owner of the land migrated to India during the liberation war of Bangladesh in 1971. At that time the site was mostly a pond and the land was flooded yearly. The inhabitants elevated the land gradually in the course of time. Figure 1 shows the morphological land development scenario of the study area in different phases by the inhabitants. In recent years, a river dam has been developed by government to protect the human settlements from flooding. Although, lower portion of the site still gets flooded in the rainy seasons.

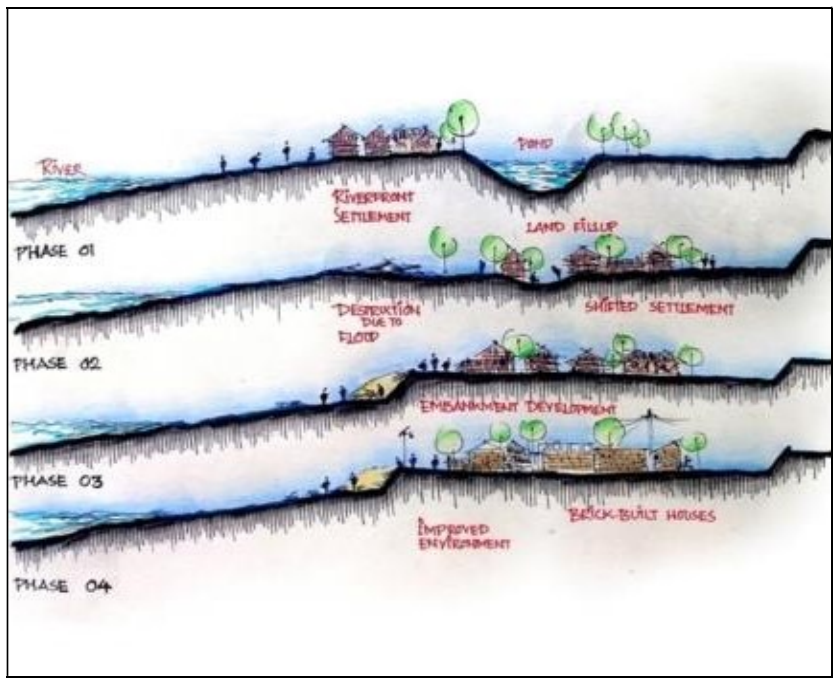

Figure 1: Morphological land development section of the study area.

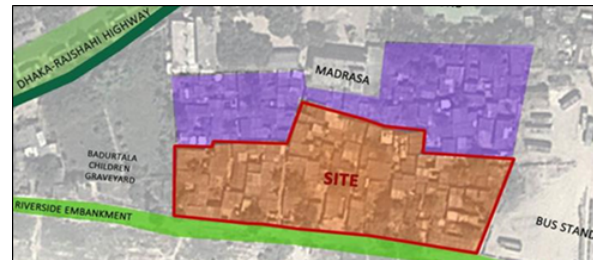

(a) Satellite map of the study area PADMARIVER

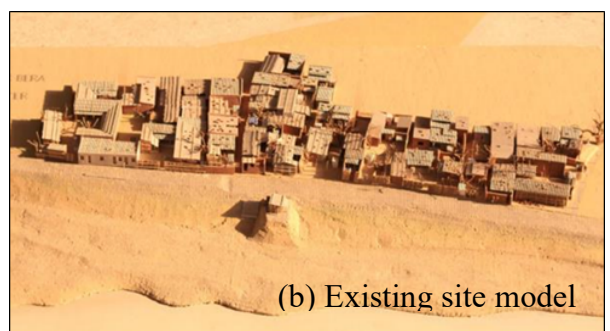

Figure 2: Site surroundings of Talaimari informal settlement, Rajshahi.

With the collaboration of UNDP this research tried to work on how to develop the habitability context of an informal settlement by the bank of river Padma, Talaimari, Rajshahi. Every year significantly in monsoon season the water level of the river raises which causes frequent floods. This flood damages char land settlement, infrastructure and communication networks (Islam et al., 2010). The only protection exists for this slum to prevent the flood is a riverside embankment which is shown by a green belt in Figure 2(a). This settlement differs slightly from the orthodox informal settlements. One of the most significant factors of informal settlement is its temporary quality, whereas our site has a handsome portion of permanent structures. Figure 2(b) helps us to understand about the density of physical structure (housing density). Like a typical Asian informal settlement this slum is densely populated with significant number of permanent structures. There are numerous other socio-cultural factors that differ this site from other informal settlements. So, the real question was, how to upgrade the habitability condition of people in such a context?

Throughout the course of our study, this research tried to come up with an answer to the question. This research exercised different options in groups and came up with design proposals, which is presented in this report. We hope that, the effort can make an impact on the lives of these people and the people living in the similar context.

\section{METHODOLOGY}

This research follows the qualitative methods which is focused on data collection and analysis. Field observations, detailed interviews, group interviews and focus group discussions were part of these activities. Furthermore, the collected data have been added to provide contextual insights through field notes or household visits. A total of 120 participants, mainly household heads, were included in the study. There has been a total of 52 households in the study area. Thirty of them were led by women and twenty-two of them had dual heads. The diversity of household heads offers rich and comprehensive information on the perspectives of their daily lives. 
Almost all categories of working people (employed, unemployed, child laborers) are interviewed. The experiences of every individual show how their daily life is measurable due to the threat of eviction.

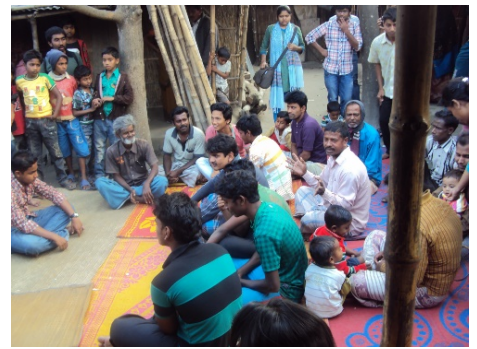

(a) Discussion session with male headed

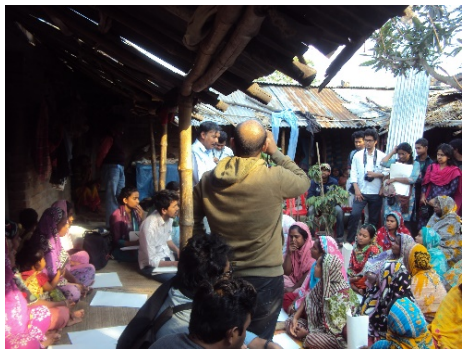

(b) Discussion session with female headed

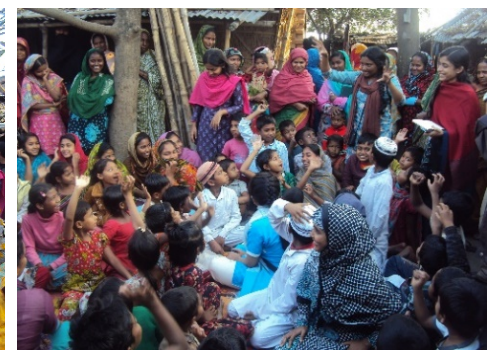

(c) Discussion session with children

Figure 3: Focus group discussion with community people.

In addition, four focus group discussions were performed with the representatives of associations at the local level (CDC-Community Development Committees), dual-headed and female-headed households and children (Figure 3). In this discussion program communities are given technical assistance for their own house design. Priority is given to the needs of individual households where the expert (design professional) tries to facilitate their preferences. Group discussions with young people were also conducted. In the study area many informal discussions were conducted with numerous individuals, including the elderly who were eager and open to provide information on their experiences with previous resettlement processes. The informants had been visited at their home. The informants had a wonderful opportunity to feel comfortable and take time to address the questions of research. NGOs (UNDP-United Nations Development Program, UPPR- Urban Partnership for Poverty Reduction) are working with this people were consulted. UPPR follows a community-based approach by mobilizing slum dwellers through Community Development Committees (CDCs) of approximately 52 households that meet regularly to determine and priorities their challenges and identify ways to address those challenges. A CDC comprises all Primary Groups (PG) in the community. A Primary Group is formed through a participatory process taking one member from each of about 15 to 20 families. They establish a CDC comprising a Group Leader and Secretary of each primary group of the community. These leaders create a capital fund from the contributions of members and external support organizations to provide their members loans to improve the security of land tenure and housing conditions. It is a member organization to provide loan finance through a revolving fund arrangement.

\section{STUDY FINDINGS AND DISCUSSIONS}

The city corporation and the development organizations needed reliable survey data and guidelines on which basis they can take initiatives to provide formal services as well as land tenure security to this informal settlement. Ample information on the tenure security and slum infrastructure development process is obtained in the application of varied qualitative methods and conversations with different informant groups. The discussion focuses on participation of people in development plans. We surveyed and analysed from different aspects of the site according to four criteria- a) Socio-cultural context; b) Natural Environment; c) Built environment and d) Socio-Economic context.

\subsection{Socio-cultural Context}

\subsubsection{Time Framed Activity}

6:00 am -10:00 am. In this period of the day the semi outdoor space and the court yards of the houses are mostly vibrant due to the rush for food preparation, getting ready for school and work. At the same time the front roads of each houses remain equally vibrant.

10:00 am to 4:00 pm. At this time the rush of the morning decreases in the internal roads of the slum. Anyhow, activity in the courts yard and semi outdoor spaces of the house remain all the same due to the household activities of the women.

4:00 pm-8:00pm. From afternoon to dusk, the internal roads of slum remain extremely vibrant with the people of all age groups. Adults use this road as their social interaction place and the children use as their playing ground. In-house activity is much less at this time. 
8:00 pm to 12:00 am. In this time period most of the activity circles around the house are performed mostly in indoor and semi-outdoor spaces. The river bank remains vibrant almost throughout the day, but in this time, some drug related illegal activities are also happened here.

The space sequence where the community's daily house hold activities are performed can be divided into four tiers- (i) Public space (the embankment), (ii) Courtyard or family sharing space, (iii) Semi outdoor space and (iv) Indoor space (Figure-4).

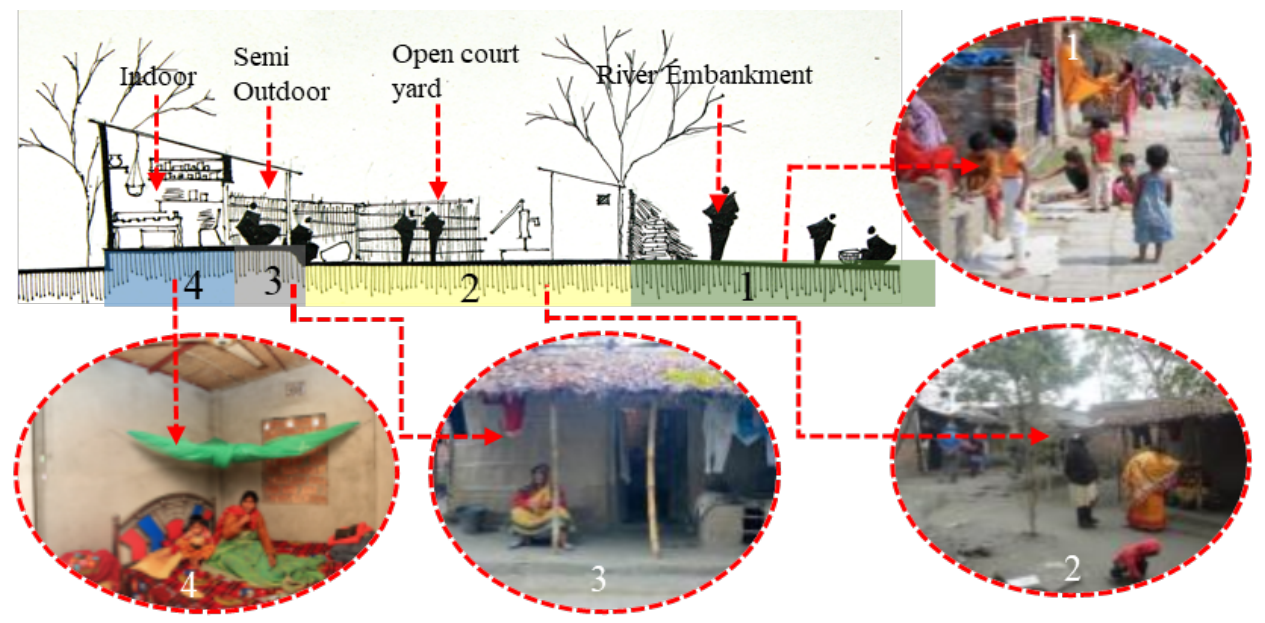

Figure 4: Space sequence with house hold activities and road.

\subsubsection{Road Activity}

The river embankment works as a main approach road of this slum which is always active with people of different age groups. Few women do their household works there and working men also remain active here. The children play among themselves and interact with outside community mates on this road. Many of the community people pass their leisure time by playing cards, walking and gossiping here. The internal road plays a vital role for the household activities. Although the internal roads are very narrow, they are used as utility space for many household chores in this highly densed site.

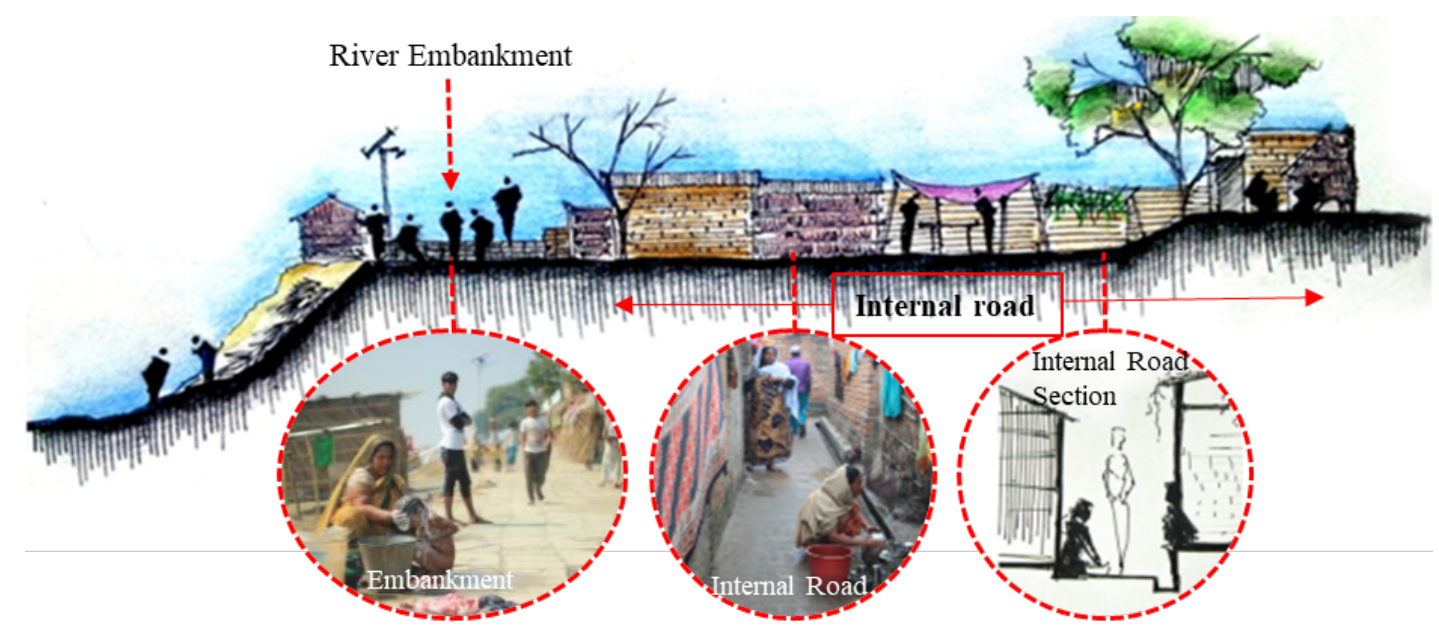

Figure 5: Section with road side activity.

\subsubsection{Relationship Mapping}

For relocation of several house holds on site (in situ) it is necessary to understand the complex livelihood relationship among the community people. Relocation is not an easy task here, as every household is interdependent with other households. We surveyed each and every household to find out their family relationships and found that many of them are family relatives living as a separate household. Usually, they 
prefer to live beside their relative household and share the house spaces and some common services among the relatives. So, an interdependent complex livelihood mechanism has already been developed here where an indiscriminate relocation means the fall down of this ecosystem. In Figure 6 the same colour indicates the family relative households. Some land occupier has built separate houses to rent, as no household of this community is land owner, either they are land occupier or renter. The green color in Figure 7 indicates the location of tenant houses which are constructed and rented by the land occupier and we found 12 families of this community are renter.

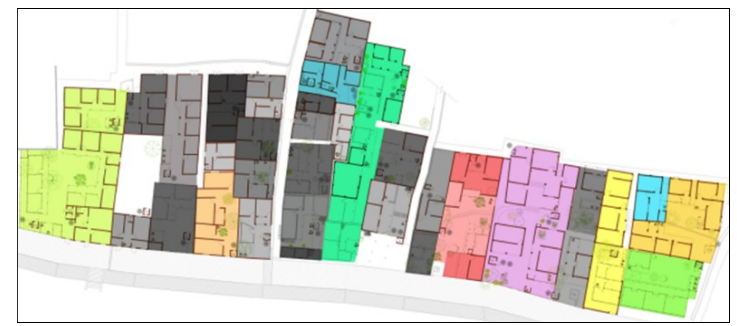

Figure 6: Relationship map among the households.

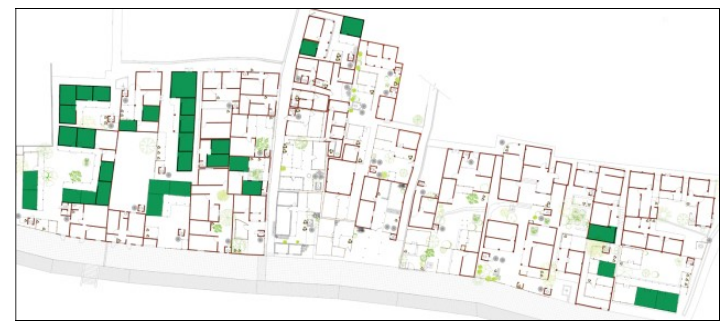

Figure 7: Location of tenant houses.

\subsection{Natural Environment}

According to population density the total slum area is divided into three sections- i) highly dense area, ii) middle dense area and iii) comparatively low dense area. The study area has totalled 52 households and the average density of the households compare to the site area is almost 1 household per 200 square feet. As the highly dense area is located in a sandwich position between middle dense area and low dense area, light and air ventilation are very crucial in this section (Figure 8a) as well as the expansion of house building is not an easy task for the increased family members. The internal road network plays the major role for air circulation in the habitable area. The Padma river is situated in the south side of this slum and it is elongated in east west direction towards the river flow as well as the internal road connections are perpendicular to the river flow direction (Figure $8 \mathrm{~b}$ ). Rajshahi has the tropical wet and dry climate, the summer breeze flows from south end to north end and it's a common practice for people to utilize this breeze for ensuring thermal comfort. Using these narrow channels (internal roads) wind passes through the slum area that ensure the minimum level of air circulation in built environment. As we discussed before, the land area of this slum was originally a wet land and the inhabitants gradually elevated the land for a minimum level of dwelling condition, the land is still lower in height compare to average ground level which makes flooding during the monsoon season. Several times the runoff water from river overflows the embankment and the slum area is flooded away. The inhabitants ensured us that almost one fourth portion of this slum is flooded way in rainy season and water level rises up to 1 ' or 1'6". In Figure 8(c) the blue marked area indicates the specific water-logged portion of the slum area. This slum is running through lack of drainage system to maintain urban flash flood that causes serious level poor sanitation and unhygienic condition. Like any other slum in Bangladesh there is a scarcity of fresh drinking water in this slum, especially in rainy season the scenario become the worst to access the drinking water for inhabitants. The community doesn't have any supply water service, the majority of the households (95\%) depend on the community tube well which is installed by Rajshahi city corporation, a small minority of households $(2 \%)$ rely on individual tube well and 3\% households depend on neighbouring household's tube well for drinking water and household purposes. At rainy season, the community tube well flooded away and they become bound to drink nearby river water which is impure that causes many water-borne diseases like cholera, typhoid and diarrhoea. Rain water can be a good source of drinking water. The majority of the households $(90 \%)$ have access to electricity service and a few of them (30\%) have satellite cable connection. 53\% slum dwellers use community latrine provided by UPPR (Urban Partnership for Poverty Reduction), 30\% households have individual latrine and $17 \%$ households have shared latrine. The latrines provided by UPPR are unhealthy and unhygienic condition though they are so called sanitary latrines.
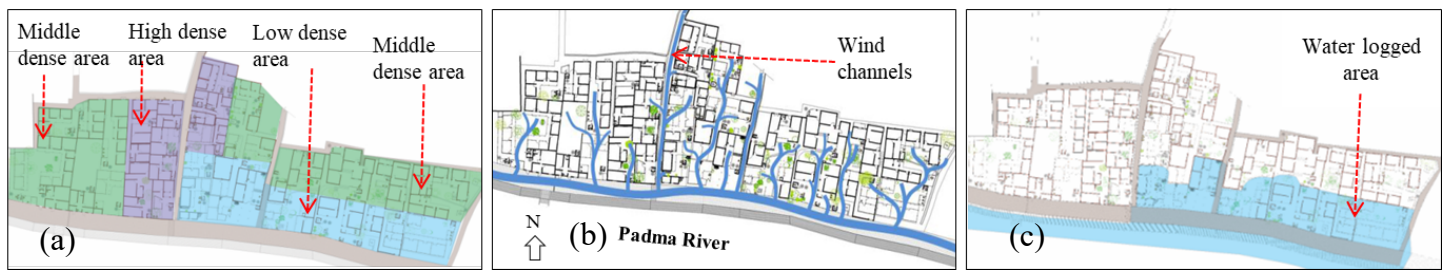

Figure 8: Population density, air ventilation and water logging scenario of the study area. 


\subsection{Built Environment}

The total area of the slum is 43115 square feet where built up area is 32118 square feet and $9.68 \%$ of this area is road infrastructure. $23.78 \%$ is open space which is mainly road area and open court yard. $10 \%$ of this land is semi outdoor space and $1.03 \%$ is indoor space. About 40 years ago after the liberation war of Bangladesh this area was be occupied by homeless people and this slum has been built. Those families who came first occupied more land according to their need. Day after day the number of homeless people increased and this land became too small to accommodate these homeless people. Unequal land distribution exists here because any of the occupants did not compromise the land property they occupied to others. Only few of them have compromised the land to their homeless blood relatives. So, for a fair plot distribution it is necessary to understand the time period of every occupant from when they live in this slum. From interview of every household, we managed to get information the occupancy time period of every occupant in this slum (Figure 9). On the basis of occupancy in course of time the study area can be divided into four time periods- (a) 40 to 30 years; (b) 30 to 20 years; (c) 20 to 10 years and (d) 10 to 0 years.
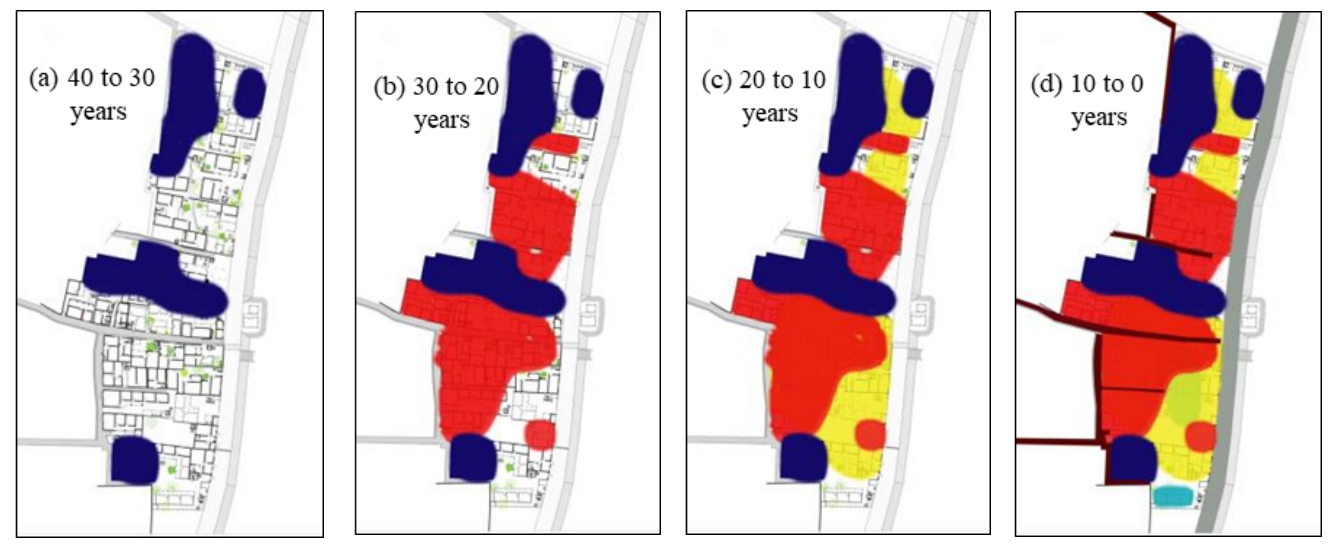

Figure 9: Occupancy types on the basis of time period.

\subsubsection{Road Network}

From Figure 10 we can generalize the entire road network of this settlement area into three categories: (a) Primary road- concrete paved river embankment, acts as the main approach road to the slum; (b) Secondary road (the internal road)- brick paved narrow lanes lying perpendicular and parallel to the embankment, passing through the slum connect the embankment to the other side (metropolitan area) of the city; (c) Tertiary roadnarrow spiral spines that connect every house courtyard and make circulation path. This mud spines work as the main entry road to many households.

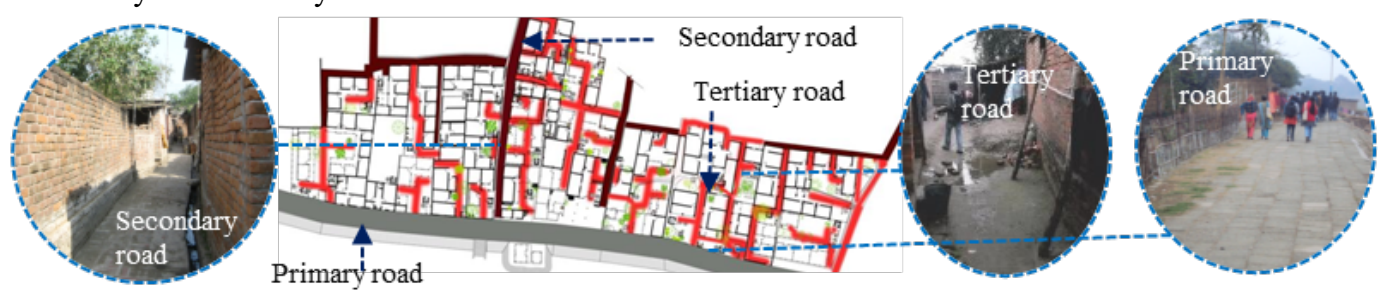

Figure 10: Multifunctional Road types in the study area.

\subsubsection{House Form}

The households make the domestic spaces fit to their way of life. In most of the cases the indoor kitchen is not used for cooking and they have transformed it into storage or bedroom. Most of the households have made expansion their building unit to outdoor kitchen and storage with temporary organic materials like thatch, bamboo and wood to serve their everyday household purposes. According to space sequence the entire house forms of this settlement can be generalized into three types (Figure 11): (a) Court yard type- a court yard is placed at centre, all the house forms are placed together around this centre (court yard), court yard type house form is much more preferable to the inhabitants because they can use this place as home income generating space also can get some spaces for house hold activities, this is the best type of house form for ensuring indoor light and air ventilation for tropical monsoon climate, $30 \%$ houses of this slum is court yard type and the actual 
number is 15 . Generally, this house form type accommodates more than one household and families within the house form. This type of house form has multiple number of kitchen and toilets. Households share semi outdoor, open court yard, kitchen and toilet among themselves. The house form in Figure 10 has some rental homes and the renter shares the addition services with the household owner; (b) Linear type- it also has a small portion of open space but not at the centre of the house form, instated of this generally the house forms are laid beside one side of the open space, this type of house is the second preference for the inhabitants, they can perform their daily house hold activities in this place, this small utility open space plays the vital role for indoor light and air ventilation, this type of house is the highest in amount which is only $44 \%$ and the actual number is 22 .

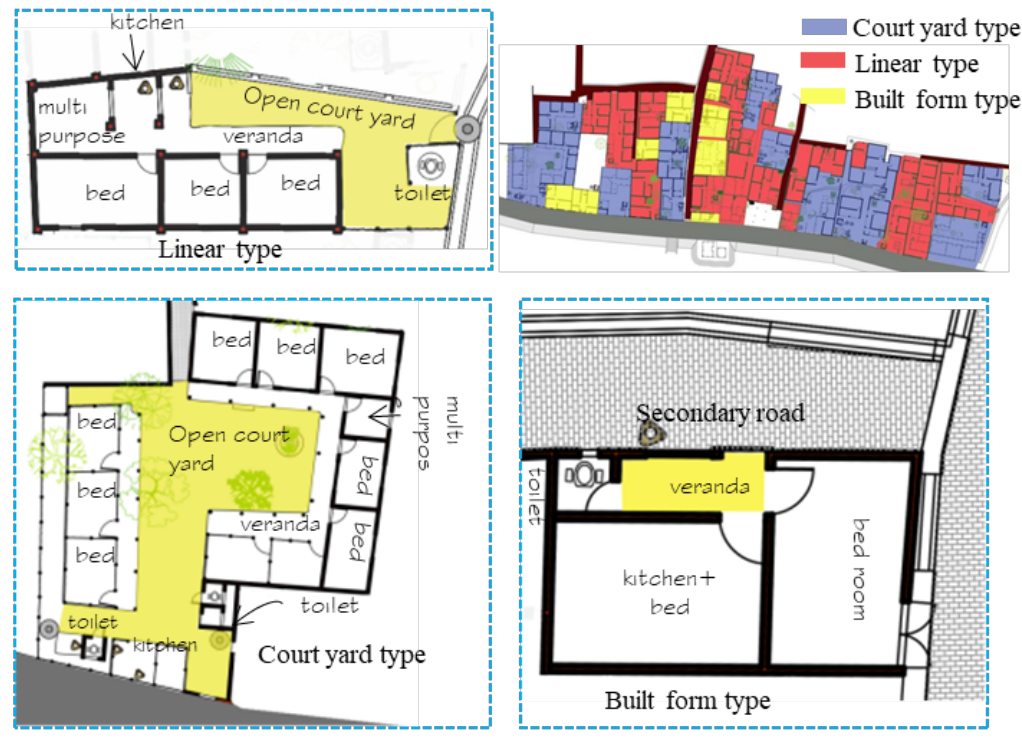

Figure 11: House form types on the basis of space sequence

This type of house form generally accommodates more than one family in a single household. If we closely look into the linear type house form in Figure 11, we will find two separate cooking stoves in a single kitchen that indicates two families share the kitchen among themselves; (c) Built form type- this type of house doesn't have any open space, only the house form. The inhabitants use their house adjacent internal road for daily house hold activities. This kind of house form is generally congested and a little amount of light and air can pass through the house. The inhabitants become bound to live in this type of house for space scarcity and the real challenge is here, planning the future generation expansion for this kind of house. Only $26 \%$ houses of this slum are built form type, the actual number is 13. The built form type house in Figure 11 is the smallest in size. The single household in this type contains a bed room, one kitchen which is also for as bed room, a small toilet and a veranda. This compact house form size is almost $280 \mathrm{sqft}$.
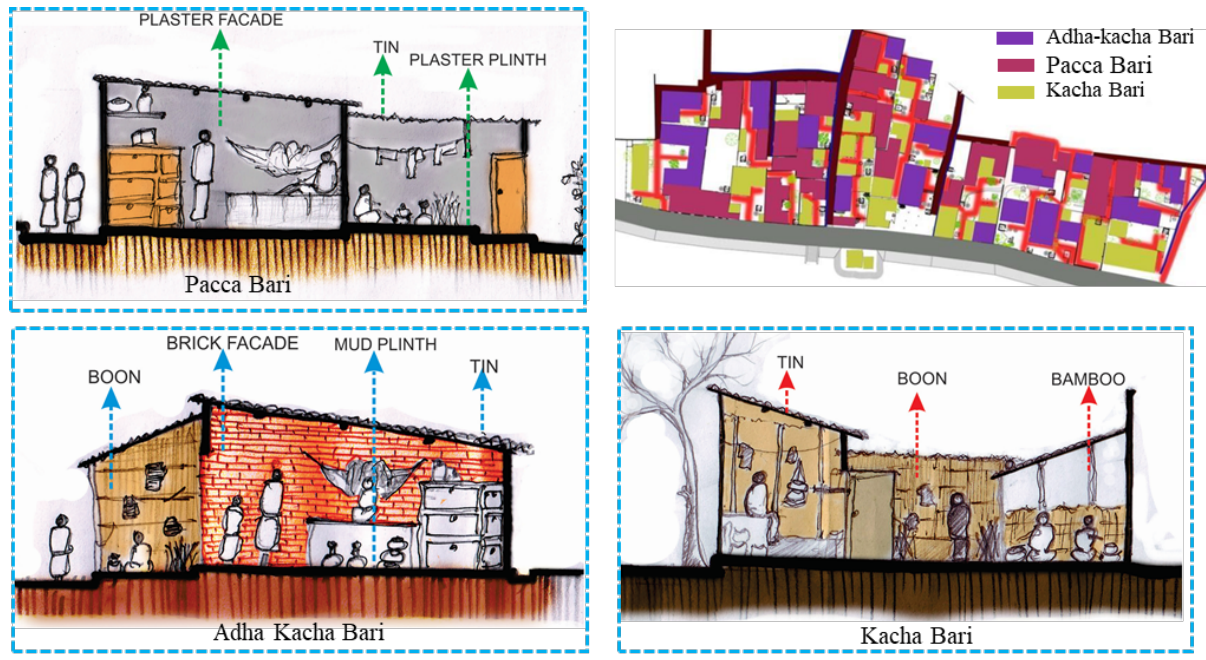

Figure 12: Built form types on the basis of building materials. 
On the basis of building materials, the built forms can be classified into three categories: a) Pacca bari (permanent structure)- the house form is generally made with plaster plinth and brick wall with plaster façade, the corrugated metal roofing sheets are used for roof construction (Figure 12). This type of houses is 11 in number and the percentage is 21.15; (b) Adha kacha bari (semi-permanent structure)- this type of built form is generally made with mud plinth and brick wall without plaster, corrugated metal roofing sheets are used for roof construction. The semi-outdoor portion of this kind of house is made with indigenous straw like plants called boon sticks (Figure 12). The char land of river Padma is the great source of boon sticks; they can get this material without paying. Adha kacha bari is the highest in number which is 28 and the percentage is 57.69; (c) Kacha bari (temporary structure)- the house form is generally built with mud plinth and boon or bamboo fences are used for wall construction, corrugated metal roofing sheets are used for roof construction (Figure 12). About $21.15 \%$ of the total built form of this slum are Kacha bari and the actual number is 11 . One of our finding is the slum area does not have any multi-storeyed built form.

\subsubsection{Shared Wall Complexity}

Like many other shared services and spaces, the slum dwellers have to share some common walls for house construction. We identified 5 number of walls which are directly being shared among the households. As an example, in Figure 13 we see a common shared wall (shared wall 3) that holds four households at a time. Though this type of housing practice is efficient for space saving but some unwanted complex situation arises among the households around this shared wall issue. Every often the question arises that who will bear cost of this common wall construction and who will bear the maintenance cost if the wall is needed to be repaired? Very often some domestic quarrelling is happened and they become violent about this issue. This issue might be one of the major obstacles of the physical development of housing and the expansion of the house form. A proper policy guideline is needed to be developed for mitigating the shared wall issue.

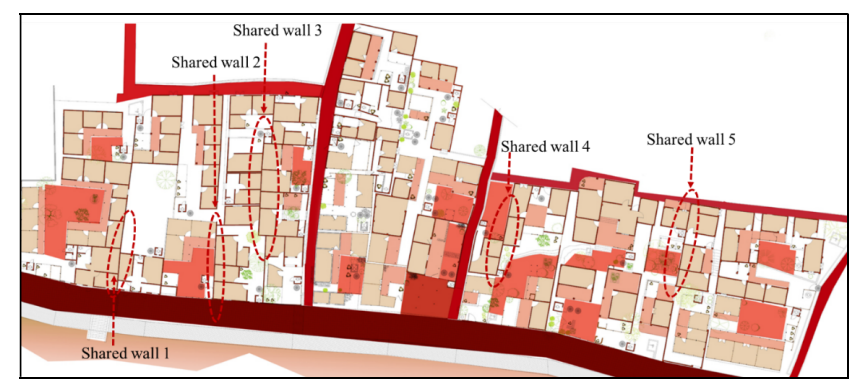

Figure 13: Shared wall mapping in the slum area

\subsection{Socio-Economic Context}

\subsubsection{Household Income}

"Affordable housing is inadequate and adequate housing is unaffordable" (UN-Habitat 2005). Slum inhabitants continue to develop their own cities, while the government and the formal market still cannot cope with growing demand for land, housing and services. (El-hadj M. Bah et al., 2018). For designing affordable housing, it essential to have a clear perception about income, expenditure, savings and banking systems of the slum dwellers. For design justice, we surveyed every individual household and collected the information of their economic activities, from 52 households we managed to collect 43 households' economic information. For example, Figure 14 represents the statistical data of every household's monthly income. In this Figure the households are named by the head of the family member. In this slum the number of members dependent on their family or non-earning is higher than the earning member.

About $54.55 \%$ people are dependent on their family for daily needs beside this the earning members are only $45.45 \%$ where the male earning member is $68.75 \%$ and the female earning member is $31.24 \%$. The slum dwellers work as industrial workers, household workers, rickshaw pullers, street hawkers, day laborers, masons etc. The range of slum dweller's household income is around 4,500Tk-15,000Tk and they have to spend most of their money for buying food. For our study purpose we have categorized the slum dwellers into three income ranges: (a) High income range- the household income is above 8,000Tk per month, from our survey we found only 8 number of households belong to this income rang and their percentage is 16; (b) Middle income rangethe household income is around 5000Tk to 7500Tk per month, we found about $39 \%$ households belong to this 
income range and their actual number is 20; (c) Low income range- the household income is around 2000Tk to $4500 \mathrm{Tk}$ per month, these income range households are the highest in number, we found $43 \%$ households belong to this income range and their actual number is 22 .

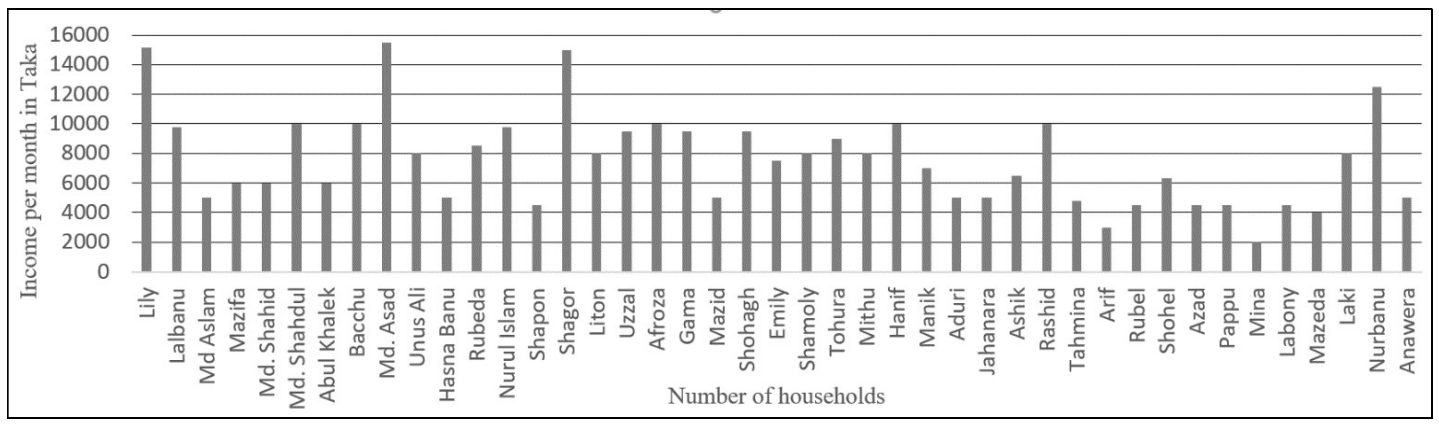

Figure 14: Household income per month in taka.

Space for infrastructure provision and income generation, enhanced security of land tenure and setting, the basis for slums upgradation (UN-Habitat, 2012b). The slum dwellers are carrying out home based income generating activities within their living environment. From table 1 we can get a clear perception about the verities of homebased economic activities and percentage ratios. Women are operating home-based business activities like community grocery shops, making street food and selling within the community area. A small glass workshop is situated within the slum area and the community women operate the workshop. The open courtyards and the inbetween spaces of built forms acts as a great source of food cultivation where women cultivate various types of seasonal vegetables which saves some of their daily expenditure on food. Some slum dwellers are raising live stokes by farming chickens, goats and cows. Cattle manure is a valuable by-product used as solid biomass fuels for cooking.

Table 1: Proportions of income generating spaces within the study area

\begin{tabular}{lccc}
\hline Category & Number & $\begin{array}{c}\text { Percentage in respect } \\
\text { to the site area }\end{array}$ & $\begin{array}{c}\text { Percentage in respect to the } \\
\text { income generating households }\end{array}$ \\
\hline Dairy farm & 2 & 4 & 18 \\
Poultry & 3 & 6 & 27 \\
Handicraft & 1 & 2 & 9 \\
Homemade food sale & 1 & 2 & 9 \\
Shop & 2 & 4 & 18 \\
\hline
\end{tabular}

\subsubsection{Household Expenditure}

For our study purpose we generalized the household expenditure data on average basis. We found about $45 \%$ of their earning is spent for food. Most of them have housing loan provided by UPPR governed community banking system CDC (Community Development Committee), about $22.7 \%$ of average income is spent for paying loan for each household. About $20 \%$ of their income is spent for house construction and maintenance. They need to repair the house twice per year that costs grossly $3150 \mathrm{Tk}$. It's a positive sign that they allocated some of their earning for education purpose though the percentage is not so high, only 10 percent. Other utility expenditure is $2 \%$ including electricity bill and satellite cable connection bill. From household expenditure per month, we can get some clear perception about household savings. The household savings varies $0.5 \%-15 \%$ from low-income range to high income range.

\subsubsection{House Making Cost}

We observed the phase wise built form development process in the study area. At initial time period the slum dwellers built Kacha house (Boon house) for living, with the development of their economic condition they started to build Adha pacca house and after that they try to build Pacca house with their more improved socioeconomic condition. A large amount of labour cost is saved in construction process because the house form is generally built in the self-assistance process by the slum dwellers. Through surveying building material accessibility of the slum dwellers and observing the market price we have estimated an approximate building construction cost of the given three types (Table 2). The slum dwellers have the opportunity of getting housing loan from CDC. From the interview survey we found many of them have capability to build more developed house form than present condition but they cannot invest so much capital because of the fear of eviction exists 
there. Like others Rubeda states that "If the authority gives us a formal permission to live in this place, we will develop our own house and the slum area by ourselves. We need permission instated of financial and other aids". Her statement indicates they have the capital to invest for quality living but with the lack land tenure security they cannot improve their living condition. Moreover, with this land tenure insecurity many of them already invested so much capital and built Pacca house. Another existing community housing practice can be supportive to this factor that in this slum area no built form has permanent roof. They make their house in this way because it will be easier for them to transfer demolished building material, if the eviction occurs.

Table 2: Building construction cost estimation

\begin{tabular}{|c|c|c|c|c|c|}
\hline $\begin{array}{l}\text { Building } \\
\text { Type }\end{array}$ & Building Size & Material Type & $\begin{array}{l}\text { Material } \\
\text { Quantity }\end{array}$ & Cost in Taka & $\begin{array}{c}\text { Grand Total } \\
\text { in Taka }\end{array}$ \\
\hline \multirow{5}{*}{$\begin{array}{c}\text { Kacha Bari } \\
\text { (Temporary } \\
\text { Structure) }\end{array}$} & \multirow{5}{*}{$16^{\prime} \times 12^{\prime}$} & Bamboo & 3 pieces & 1000 & \multirow{5}{*}{10500} \\
\hline & & Boon & $600-700$ bundle & 2800 & \\
\hline & & Corrugated metal sheet & 6 pieces & 2000 & \\
\hline & & Metal Pin & $6 \mathrm{Kg}$ & 200 & \\
\hline & & Labor & & 4500 & \\
\hline \multirow{7}{*}{$\begin{array}{c}\text { Adha Kacha } \\
\text { Bari } \\
\text { (Semi- } \\
\text { Permanent } \\
\text { Structure) }\end{array}$} & \multirow{7}{*}{$16^{\prime} \times 12^{\prime}$} & Brick & 1000 pieces & 3800 & \multirow{7}{*}{22380} \\
\hline & & Cement & 6 bags & 2880 & \\
\hline & & Sand & $250 \mathrm{cft}$ & 1500 & \\
\hline & & Bamboo & 3 pieces & 1000 & \\
\hline & & Corrugated metal sheet & 6 Pieces & 8000 & \\
\hline & & Metal Pin & $6 \mathrm{Kg}$ & 200 & \\
\hline & & Labor & & 5000 & \\
\hline \multirow{7}{*}{$\begin{array}{l}\text { Pacca Bari } \\
\text { (Permanent } \\
\text { Structure) }\end{array}$} & \multirow{7}{*}{$16^{\prime} \times 12^{\prime}$} & Brick & 2000 pieces & 7000 & \multirow{7}{*}{30000} \\
\hline & & Cement & 8 bags & 3800 & \\
\hline & & Sand & $400 \mathrm{cft}$ & 2500 & \\
\hline & & Bamboo & 3 pieces & 1000 & \\
\hline & & Corrugated metal sheet & 6 Pieces & 8000 & \\
\hline & & Metal Pin & $6 \mathrm{Kg}$ & 200 & \\
\hline & & Labor & & 7500 & \\
\hline
\end{tabular}

The community people minimize the house construction cost through: 1) maximizing re-use of building material; 2) using comparatively cheaper and indigenous construction materials; 3) applying local techniques; 4) taking technical supports from local builders; 5) participating in construction phases (self-built house). The char land of the river Padma is a great source of natural sand which is be used for building construction. The slum dwellers use this natural resource in house making for Adha kacha bari and Kacha bari. Beside this the slum dwellers actively participate and work as labourer with house builder in building their own home. Most of the cases they make the Kacha bari by themselves without the assistance of professional house builders.

\subsection{Design Guidelines from Findings}

From the above study of this informal settlement, we can get a very specific design guideline from findings through identifying indicators and variables step by step. In table 3,4,5 and 6 we have sorted out context basis study findings and their design and policy guidelines.

Table 3: Design guidelines from the findings of socio-cultural context.

\begin{tabular}{|c|c|c|c|}
\hline Findings & Indicators & Variables & Design guidelines \\
\hline \multirow[b]{2}{*}{$\begin{array}{l}\text { Strong social } \\
\text { bonding }\end{array}$} & \multirow{2}{*}{$\begin{array}{l}\text { Maximum area of this slum } \\
\text { are as sharing space }\end{array}$} & Open court yard & \multirow{2}{*}{$\begin{array}{l}\text { Some common } \\
\text { services and spaces can } \\
\text { be shared among few } \\
\text { families }\end{array}$} \\
\hline & & $\begin{array}{l}\text { Narrow spines passing } \\
\text { through different plot }\end{array}$ & \\
\hline \multirow{4}{*}{$\begin{array}{l}\text { Maximum } \\
\text { utilization of } \\
\text { physical spaces }\end{array}$} & $\begin{array}{l}\text { The place for community and } \\
\text { family festivals. }\end{array}$ & $\begin{array}{l}\text { River embankment and } \\
\text { house courtyard }\end{array}$ & \multirow{4}{*}{$\begin{array}{l}\text { Multipurpose uses of } \\
\text { physical spaces }\end{array}$} \\
\hline & $\begin{array}{l}\text { Recreational and community } \\
\text { gathering place. }\end{array}$ & River embankment & \\
\hline & $\begin{array}{l}\text { Places for household chores } \\
\text { outside the home. }\end{array}$ & Internal road & \\
\hline & Children's playing ground. & $\begin{array}{l}\text { Internal road and river } \\
\text { embankment }\end{array}$ & \\
\hline
\end{tabular}


Table 4: Design guidelines from the findings of the context of natural environment.

\begin{tabular}{|c|c|c|c|}
\hline Findings & Indicators & Variables & Design guidelines \\
\hline \multirow[b]{2}{*}{ Flooding } & \multirow{2}{*}{$\begin{array}{l}\text { Water logging in } \\
\text { the study area }\end{array}$} & Low land & \multirow{2}{*}{$\begin{array}{l}\text { The river embankment height should be raised } \\
\text { as well as planning permanent drainage system }\end{array}$} \\
\hline & & $\begin{array}{l}\text { Lack of proper } \\
\text { drainage system }\end{array}$ & \\
\hline \multirow{2}{*}{$\begin{array}{l}\text { Scarcity of water } \\
\text { and sanitation }\end{array}$} & $\begin{array}{l}\text { Impure drinking } \\
\text { water }\end{array}$ & $\begin{array}{l}\text { Water borne } \\
\text { diseases }\end{array}$ & \multirow{2}{*}{$\begin{array}{l}\text { Planning some deep tube wells for cluster } \\
\text { based families }\end{array}$} \\
\hline & $\begin{array}{l}\text { Inaccessibility to } \\
\text { fresh drinking } \\
\text { water }\end{array}$ & $\begin{array}{l}\text { Source of } \\
\text { drinking water far } \\
\text { away from home }\end{array}$ & \\
\hline
\end{tabular}

Table 5: Design guidelines from the findings of the context of built environment.

\begin{tabular}{llll}
\hline \multicolumn{1}{c}{ Findings } & \multicolumn{1}{c}{ Indicators } & \multicolumn{1}{c}{ Variables } & \multicolumn{1}{c}{ Design guidelines } \\
\hline $\begin{array}{l}\text { Strong } \\
\text { communication }\end{array}$ & $\begin{array}{l}\text { All houses are } \\
\text { connected together }\end{array}$ & $\begin{array}{l}\text { Narrow spine roads } \\
\text { connect one house to } \\
\text { another }\end{array}$ & $\begin{array}{l}\text { Improved connectivity (physical and } \\
\text { visual) can enhance social } \\
\text { surveillance }\end{array}$ \\
\hline $\begin{array}{l}\text { Passive climate } \\
\text { control }\end{array}$ & $\begin{array}{l}\text { Built form space } \\
\text { sequences }\end{array}$ & $\begin{array}{l}\text { Semi-outdoor oriented } \\
\text { house activities }\end{array}$ & $\begin{array}{l}\text { Climatic comfort can be ensured by } \\
\text { providing more semi-outdoor spaces }\end{array}$ \\
\hline $\begin{array}{l}\text { Self-assisted house } \\
\text { making obstacles }\end{array}$ & $\begin{array}{l}\text { Complex issue about } \\
\text { shared service }\end{array}$ & $\begin{array}{l}\text { Shared wall } \\
\text { complexity }\end{array}$ & $\begin{array}{l}\text { A specific policy framework can } \\
\text { mitigate shared wall complexity }\end{array}$ \\
\hline
\end{tabular}

Table 6: Design guidelines from the findings of socio-economic context.

\begin{tabular}{llll}
\hline \multicolumn{1}{c}{ Findings } & \multicolumn{1}{c}{ Indicators } & \multicolumn{1}{c}{ Variables } & \multicolumn{1}{c}{ Design guidelines } \\
\hline $\begin{array}{l}\text { Familiar with } \\
\text { formal banking } \\
\text { system }\end{array}$ & $\begin{array}{l}\text { The community's own } \\
\text { banking system }\end{array}$ & $\begin{array}{l}\text { CDC (Community } \\
\text { Development } \\
\text { Community) }\end{array}$ & $\begin{array}{l}\text { CDC can provide the initial } \\
\text { housing loan to the slum } \\
\text { dwellers }\end{array}$ \\
$\begin{array}{ll}\text { On site income } \\
\text { generating } \\
\text { opportunities }\end{array}$ & $\begin{array}{l}\text { Home based income } \\
\text { generating spaces }\end{array}$ & $\begin{array}{l}\text { Utilization of courtyard, } \\
\text { in-between spaces of } \\
\text { built forms }\end{array}$ & $\begin{array}{l}\text { Larger size open court yard can } \\
\text { enhance the income generating } \\
\text { activities }\end{array}$ \\
\hline
\end{tabular}

Table 7 represents the structured analysis of the study area from the above mentioned fourth contextual perspectives that illustrates strength, weakness, opportunity and possible threat of the study area.

Table 7: Strength, weakness, opportunity and threat analysis of the study area

\begin{tabular}{|c|c|c|c|c|}
\hline Context & Strength & Weakness & Opportunity & Threat \\
\hline 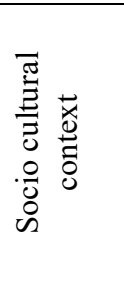 & $\begin{array}{l}\text { - Strong neighborhood } \\
\text { relationship } \\
\text { - Community sharing } \\
\text { - Dense living ensures } \\
\text { social surveillance } \\
\text { - Women's participation } \\
\text { in economic activities }\end{array}$ & $\begin{array}{l}\text { - Lack of tenure } \\
\text { security }\end{array}$ & $\begin{array}{l}\text { - Opportunity to provide } \\
\text { common sharing } \\
\text { spaces and services } \\
\text { among the community } \\
\text { people } \\
\text { - Multipurpose activities } \\
\text { of river embankment }\end{array}$ & $\begin{array}{l}\text { - Highly } \\
\text { vulnerable as } \\
\text { social crime } \\
\text { zone } \\
\text { - Separation by } \\
\text { boundary wall } \\
\text { - Drug dealing }\end{array}$ \\
\hline 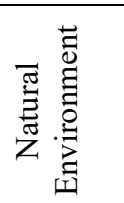 & $\begin{array}{l}\text { - Availability of sand } \\
\text { and soil } \\
\text { - River base settlement }\end{array}$ & $\begin{array}{l}\text { - Low level of } \\
\text { ground soil } \\
\text { - Insufficient light } \\
\text { and air ventilation }\end{array}$ & $\begin{array}{l}\text { - Introducing some } \\
\text { agricultural activities } \\
\text { in embankment }\end{array}$ & $\begin{array}{l}\text { - Increase of } \\
\text { water level } \\
\text { during rainy } \\
\text { season } \\
\text { - Water logging }\end{array}$ \\
\hline 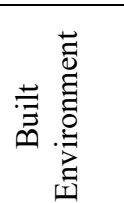 & $\begin{array}{l}\text { - Court yard type living } \\
\text { - Horizontal } \\
\text { development } \\
\text { - Influential semi- } \\
\text { outdoor space }\end{array}$ & $\begin{array}{l}\text { - Narrow } \\
\text { circulation spines } \\
\text { - Water supply and } \\
\text { sanitation } \\
\text { problem }\end{array}$ & $\begin{array}{l}\text { - Vertical extension of } \\
\text { built form } \\
\text { - Community space } \\
\text { development }\end{array}$ & $\begin{array}{l}\text { - Horizontal } \\
\text { encroachment of } \\
\text { densely } \\
\text { populated } \\
\text { settlement }\end{array}$ \\
\hline
\end{tabular}




\begin{tabular}{lcccc}
\hline Context & \multicolumn{1}{c}{ Strength } & \multicolumn{1}{c}{ Weakness } & \multicolumn{1}{c}{ Opportunity } & Threat \\
\hline & $\bullet$ Idea of selling & $\bullet$ Scarcity of & $\bullet$ Reducing expenditure & $\bullet$ Illegal income \\
through increasing of & source (drug \\
homemade food & economic sources & $\begin{array}{l}\text { throug } \\
\text { home-based economic } \\
\text { activities }\end{array}$ & dealing) \\
\hline 0 & beside the street & within the site & & \\
\hline
\end{tabular}

\section{ARCHITECTURAL INTERVENTIONS}

\section{$5.1 \quad$ Relocation}

Studying the slum dweller's existing livelihood condition and their interdependent livelihood mechanism, it can be easily understood that the random relocation of the households means the fall down of the existing livelihood ecosystem. We can create interactive space through remaining them in their previous condition rather relocating them in a new site. We have made policies and proposals on the basis of maximum retention and minimum relocation. But for ensuring better living condition in the slum area a few numbers of households should be relocated from high dense area to low dense area. For this purpose, five numbers of households have been relocated within the slum area in our proposed master plan (Figure 15). This relocation proposal has been made regarding to the slum dwellers investment on housing and the relationships (family relatives) to their immediate neighbourhoods. On the basis of investment \& long duration of staying, thoroughly minimum relocation is more logical that gives maximum retention.

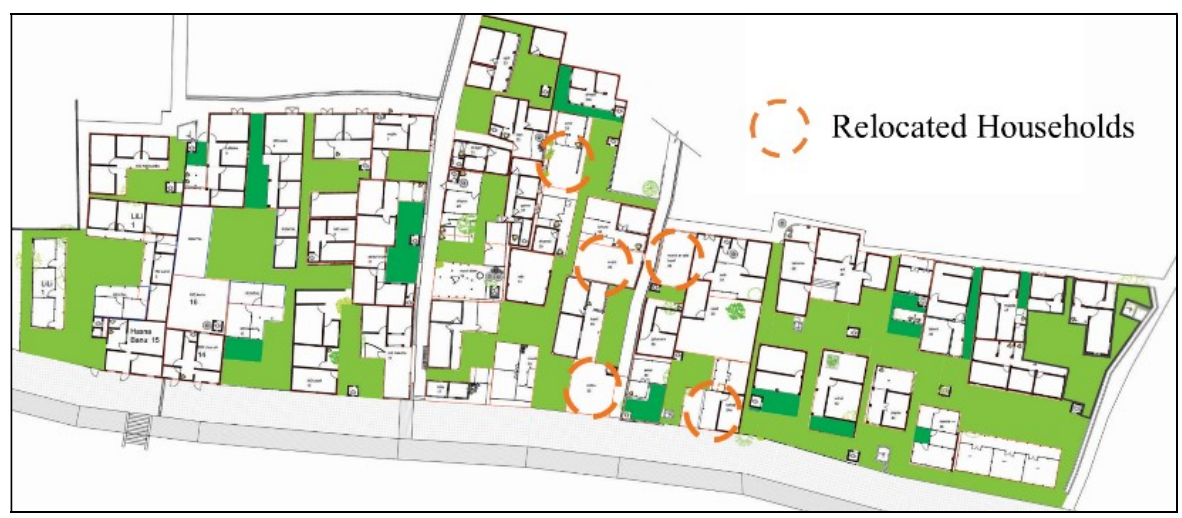

Figure 15: Relocated households in proposed masterplan.

\subsection{Tenure Security}

\subsubsection{Plot Distribution}

In distributing plots among to the households the major driven factors were the inhabitant's belongingness (long duration of staying), their investment on housing and their basic needs in respect to the context of this slum area. Each existing household will get 300 square feet housing area including a bed room, a multipurpose room, a kitchen area and a semi outdoor space (Figure 16). This is the minimum house size for four member's household in respect to this slum area. After getting this plot size, additional plot area will be added considering their duration of staying (tenureship) and housing investment. The open space or house adjacent courtyard will be provided as shared space among the multiple households. Each householder will get 124 square feet which is minimum standard in respect to the specific site. We have developed a mechanism in order to make relation between tenureship and additional plot size for plot distribution. The plot holders whose duration of staying in this slum is around 0 to 10 years, will get 10 percent share of the open space (house court yard). The plot holders whose duration of staying in this slum is around 11 to 20 years, will get 20 percent share of the open space. The plot holders whose duration of staying in this slum is around 21 to 30 years, will get 30 percent share of the open space. The plot holders whose duration of staying in this slum is around 31 to 40 years, will get 40 percent share of the open space. We can get the information on the household's duration of staying from the survey study of occupancy types based on the time period that is mentioned in section 4.3 (Figure 9). Each individual plot holders will get 10 percent of habitation space according to their investment. Each house will get the opportunity to rent their open court yard as an income generating space. If we follow this framework, it is possible to distribute the plot in the most relevant way among the slum dwellers for authority without relocating 
the households except the above mentioned five numbers. The plot distribution map is shown in Figure 17. Most importantly, the families will not get the plots right away. If they get the plot right now, they may sell the land or build unplanned houses. So initially they would get only the land needed for the house at lease for 20 years. After that, if they conduct their end of the contract honestly, they will own the plot.

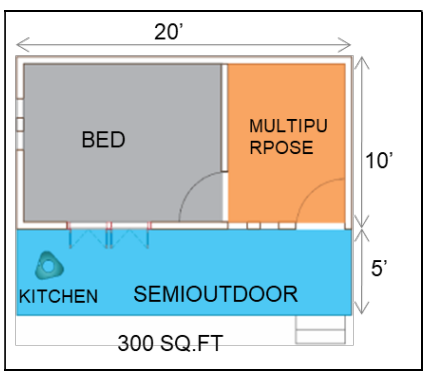

Figure 16: Standard household size.

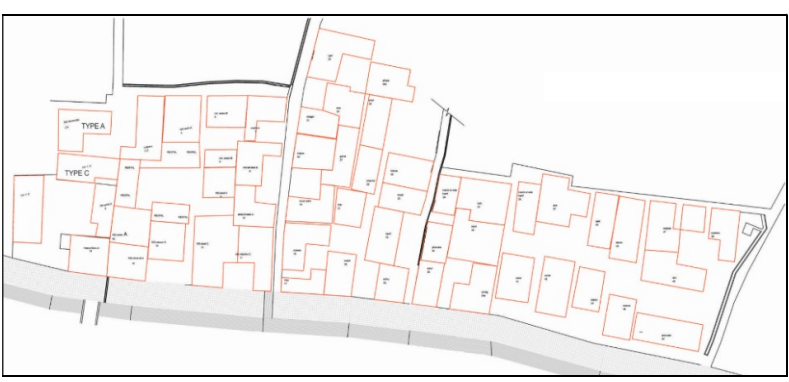

Figure 17: Plot distribution map.

\subsection{Future Generation Expansion}

\subsubsection{House form expansion}

From the previous study and context analysis of this slum area, we enhanced courtyard-oriented living environment for designing climate responsive built environment as well as maximizing the uses of spaces. We tried to Figure out the individual unit and cluster unit built-form model for future generation expansion. Cost effectiveness, materials availability, locally available techniques were the main driving forces behind the housing design. We designed phase-wise house development proposal where the slum dwellers can build their desired house according to their financial ability. In table 8, we see the four phases of house development.

Table 8: Proposed house development phases.

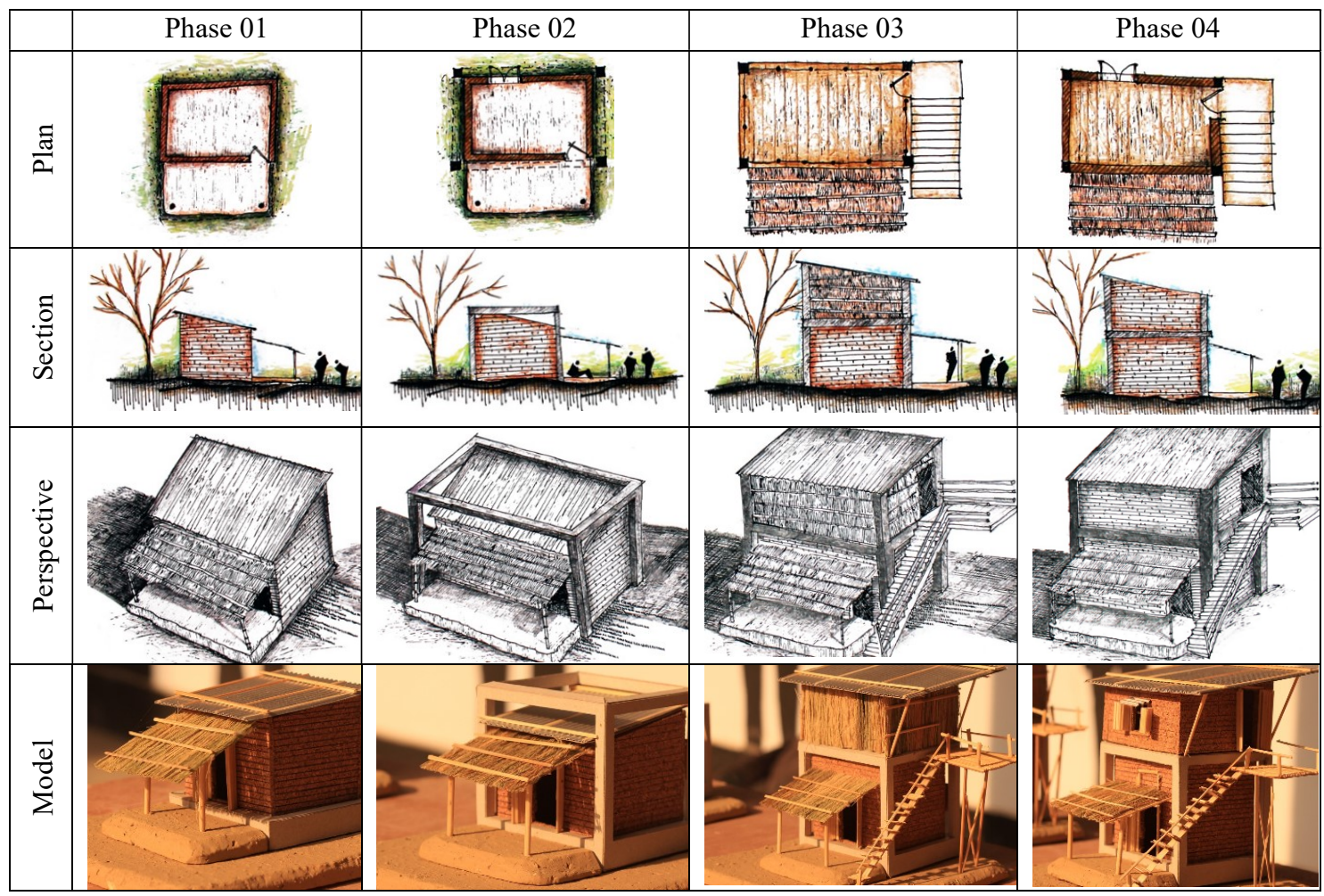

The first phase is Kacha house, made with boon and bamboo. The second phase is Adha kacha house, made with brick and corrugated sheet. The third phase is the vertical extension where the intermediate floor slab will 
be built with bamboo or wood and the extended portion will be built with bamboo and boon. At the fourth phase, the second storey will also be built with brick and mortar and the intermediate floor slab will be replaced with concrete slab. Four corner columns must be built with concrete at the beginning of phase one that requires a minimum level of footing base. At stage two four reinforced concrete beams will tie upon the four concrete columns that seem like an organic home hanging under a concrete frame. At stage three a steel stair will be added for vertical circulation and initially a wooden floor slab will serve as the intermediate floor slab. At the initial stage, the CDC provides housing loans with low interest to the slum dwellers according to their income range. In the existing condition space ratio between the built-up area and the open space are 75 percent and 25 percent. After implementing the plot distribution and design guidelines this ratio will be 60 percent for the builtup area and 40 percent for open space. Table 9 represents a gross cost estimation for phase-wise house development.

Table 9: Phase-wise house development cost estimation.

\begin{tabular}{|c|c|c|c|c|}
\hline $\begin{array}{c}\text { Building } \\
\text { Development Phases }\end{array}$ & Material Type & Material Quantity & Cost in Taka & $\begin{array}{c}\text { Grand Total } \\
\text { in Taka }\end{array}$ \\
\hline \multirow{6}{*}{ Phase 01} & Bamboo & 3 pieces & 1000 & \multirow{6}{*}{12075} \\
\hline & Boon & 150 bundle & 700 & \\
\hline & Corrugated metal sheet & 6 pieces & 2000 & \\
\hline & Brick & 1000 pieces & 3800 & \\
\hline & Metal Pin & $2 \mathrm{Kg}$ & 75 & \\
\hline & Labor & & 4500 & \\
\hline \multirow{4}{*}{ Phase 02} & Footing construction & & 2000 & \multirow{4}{*}{35000} \\
\hline & Beam construction & & 16000 & \\
\hline & Column construction & & 12000 & \\
\hline & Labor & & 5000 & \\
\hline \multirow{6}{*}{ Phase 03} & Bamboo & 3 pieces & 1000 & \multirow{6}{*}{15000} \\
\hline & Boon & 150 bundle & 700 & \\
\hline & Steel Stair & 1 piece & 7200 & \\
\hline & Bamboo slab & 3 pieces & 3000 & \\
\hline & Metal Pin & $3 \mathrm{Kg}$ & 100 & \\
\hline & Labor & & 3000 & \\
\hline \multirow{3}{*}{ Phase 04} & Brick & 1000 pieces & 3800 & \multirow{3}{*}{60800} \\
\hline & Concrete Slab & & 50000 & \\
\hline & Labor & & 7000 & \\
\hline
\end{tabular}

\subsubsection{Sharing wall construction policy}

One of the major challenges of this research is to provide an advisable as well as practical guidelines for solving the existing sharing wall complexities. The CDC will play a vital role in sharing wall construction agreement between the two or more households. If the two households adjacent to a single share wall are agreed to extend their house form according to the design guidelines, each household has to bear 50 percent construction cost of the sharing wall with mutual agreement. In this case, the CDC's role play does not require. If one household is interested to extend the house form and another one delays, for this circumstance the CDC will fund for the entire sharing wall construction. At first the interested household has to buy 100 percent share of the sharing wall from CDC. When the another household will be able to extend, he must buy the another fifty percent share with current market price from the first house hold and the first household must be obliged to sell the rest 50 percent share to the second household. The CDC will monitor the entire agreement process. Until the extension of the house form of second household, the first household will get every opportunity from the sharing wall. The same guideline can be followed in sharing wall maintenance policies.

\subsubsection{Physical environment improvement}

Through increasing activity \& accessibility of streets throughout the slum area and installing some street lights, the social crime can be reduced. In our proposed masterplan we have fixed some dead ends of the internal roads without forcing out any built form that will ensure more social surveillance. As the percentage of open space rises from 25 percent to 40 percent, the slum dwellers will get more opportunities to perform their home-based income generating activities like gardening and cattle farming. Raising the river embankment up to 2 feet from 
the existing height can be effective for water logging prevention. At the house form development phase in the low land area of this slum adjacent to the embankment, the inhabitants also need to develop their land level up to the same level as the embankment. Although UPPR provides some community toilet and deep tube well but these number are not sufficient in respect to the slum size. Installing some more community deep tube well with help of UPPR can reduce scarcity of drinkable water. In Figure 18 we can visualize the future scenario of our study area.
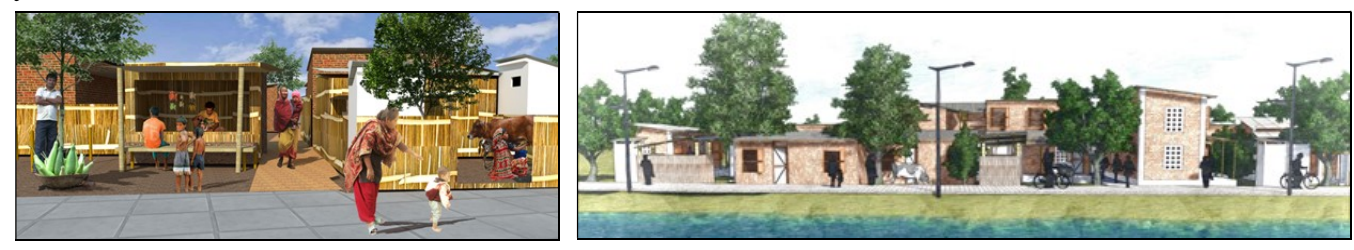

Figure 18: Visualization of the future vision.

\section{CONCLUSIONS}

This essay attempts to explain the many dynamic social and economic problems of urban informal settlements. The study exposes the underlying challenges of the informal settlement and illustrates how the challenges can be optimized through architectural interventions. This research tried to provide some practical design solution for optimizing housing density in the slum area through built form extension policy. An innovative cost-effective housing design solution is introduced to the slum dwellers which they can easily afford and can be built by themselves. The built form type solution will enhance the existing community bonding among the slum dwellers which is their key strength of survival. This study shows how the slum dwellers can improve their living conditions within the boundary of the existing scarcity. It also reveals some income generating opportunities within the study area. The findings evidently demonstrate that the livelihoods of the informal settlement areas are impoverished and heavily inhabited with inadequate and minimal public goods and low civic standards. This study provides a policy guideline to these development authorities on which basis they can provide land tenure security and other civic services to the slum dwellers. Minimum intervention is made in making these design guidelines in which the relocated families will get better opportunities. We tried to make a "win-win situation" among the slum dwellers so that a quality living as well as the design justice can be ensured through architectural design interventions.

Though we want to do minimum relocation, maximum retention, in that case five plot holders have been relocated. Two plot holders get below the basic need (300sq.ft criteria). In order to keeping the existing sociocultural setup, in distribution of open space equal distribution could not be possible among all the clusters. For the same reason the existing internal road width expansion could not possible. For narrow road width in emergency situation, the services like ambulance service and fire service vehicle accessibility will be critical. With the possibility of vertical expansion, there is a chance that in the long run, the site will again lose its openness. There is no define way by which the people of this settlement can enhance their income source.

\section{REFERENCES}

Abebe, F. K. (2011). Modelling informal settlement growth in Dar es Salaam. Unpublished Master's Thesis, University of Twente, The Netherlands.

Abebe, G., \& Hesselberg, J. (2015). Community participation and inner-city slum renewal: relocated people's perspectives on slum clearance and resettlement in Addis Ababa. Development in Practice, 25(4), 551562.

Afsar, R. (2000). Rural-urban migration in Bangladesh: Causes, consequences, and challenges. Dhaka: University Press.

Ahmed, I. (2016). Building resilience of urban slums in Dhaka, Bangladesh. Procedia - Social and Behavioral Sciences, 218, 202-213.

Arputham, J. (2008). "Developing New Approaches for People-Centered Development." Environment and Urbanization 20 (2): 319-337.

Asian Development Bank (2011), “Asia 2050: Realising the Asian Century”.

Banks, N. (2008). "A Tale of Two Wards: Political Participation and the Urban Poor in Dhaka City." Environment and Urbanization 20 (2): 361-376.

Bari, M. \& Efroymson, D. (2009). Detailed area plan (DAP) for Dhaka metropolitan development plan (DMDP): A critical review: Dhaka: WBB Trust. And CPD 2001. 
Collier, P., Glaeser, E., Venables, A., Manwaring, P., \& Blake, M. (2017). Land and property taxes for municipal finance. International Growth Center, London School of Economic and Political Science: London, UK.

El-hadj, M. B., Faye, I., \& Geh, Z. F. (2018). Slum upgrading and housing alternatives for the poor. In Housing market dynamics in Africa (pp. 215-253). Palgrave Macmillan, London.

Fekade, W. (2000). Deficits of formal urban land management and informal responses under rapid urban growth, an international perspective. Habitat International, 24(2), 127-150.

HHB (2019). Lessons from solid ground: country case study, Upgrading informal settlements in Bangladesh. Habitat for Humanity Bangladesh (HHB). <https://www.habitat.org/sites/default/files/documents/solidground-case-study_slum-upgrading_Bangladesh.pdf $>$ (Accessed 25 september 2020).

Huq, P.A. (2013). Leading to participatory local governance? Participation, empowerment and communitydriven development. (Doctor of Philosophy), Flinders University, Adelaide.

Islam, N., Mahbub, A.Q.M., Nazem, N.I., Angeles, G., \& Lance, P.M. (2006). Slums of urban Bangladesh: Mapping and census 2005. Dhaka, Bangladesh: Centre for Urban Studies.

Islam, S. N., Singh, S., Shaheed, H., \& Wei, S. (2010). Settlement relocations in the char-lands of Padma River basin in Ganges delta, Bangladesh. Frontiers of Earth Science in China, 4(4), 393-402.

Koenig, D. (2006). "Enhancing Local Development in Development-Induced Displacement and Resettlement Projects.” In Development-Induced Displacement: Problems, Policies, and People, edited by C. Wet, 105-139. Oxford: Berghahn.

Lemanski, C. (2008). "Houses Without Community: Problems of Community Capacity in Cape Town, South Africa." Environment and Urbanization 20 (2): 393-410.

LIUPCP (2015). Evolution of Participatory and Support Based Approach for Strengthening Tenure Security, Housing and Community Resilience. Livelihoods Improvements of Urban Poor Communities Projects (LIUPCP). <http://www.urbanpovertybd.org/e_libraries/Resources/evolution-of-participatory-andsupport-based-approach-for-strengthening-tenure-security-housing-and-community-resilience $>$ (accessed 28 September 2020).

Mitlin, D. (2008). "With and Beyond the State - Co-Production as a Route to Political Influence, Power and Transformation for Grassroots Organizations." Environment and Urbanization 20 (2): 339-360.

Satterthwaite, D. (2001). Reducing urban poverty: constraints on the effectiveness of aid agencies and development banks and some suggestions for change. Environment \& Urbanization, 3.

Sen, A. (1990). "Development as Capability Expansion.” In Human Development and the International Strategy for the 1990s, edited by K. Griffin and J. Knight, 41-58. London: Macmillan.

Smets, P., \& Lindert, P. (2016). Sustainable housing and the urban poor. International Journal of Urban Sustainable Development, 8(1), 1-9.

Turok, I., \& Borel-Saladin, J. (2018). The theory and reality of urban slums: Pathways-out-of-poverty or cul-desacs? Urban Studies, 55(4), 767-789.

UN-Habitat (2003). The challenges of slums. Global report on human settlements, London, Earthscan.

UN-Habitat (2005). Financing Urban Shelter. Global Report on Human Settlements 2005. Nairobi: United Nations Human Settlements Program.

UN Habitat (2006). State of the world's cities 2006/7. Nairobi: Author. $<\mathrm{http}$ //mirror.unhabitat.org/pmss/listItemDetails.aspx?publicationID=210> (Accessed 31 September 2020).

UN-Habitat (2008). Housing the poor in Asian cities. Quick guide for the policy makers. $<$ https:/www.unescap.org/sites/default/files/QGAP_3_Land_En_0.pdf $>$ (Accessed 30 September 2020).

UN-Habitat (2009). Planning sustainable cities: global report on human settlements 2009. Nairobi.

UN-Habitat (2012a). Sustainable housing for sustainable cities. a policy framework for developing countries. Nairobi: UN-Habitat.

UN-Habitat (2012b). Streets as Tools for Urban Transformation in Slums: A Street-Led Approach to Citywide Slum Upgrading.

UPPR (2012). Urban partnerships for poverty reduction annual progress report 2012. Dhaka, Bangladesh: Urban Partnerships for Poverty Reduction.

Wainer, S., Ndengeyingoma, B., \& Murray, S. (2016). Incremental housing and other design principles for lowcost housing. International Growth Centre Final Report C-38400- RWA-1.

Walters, P. (2018). The limits to participation: Urban poverty and community driven development in Rajshahi City, Bangladesh. Community Development, 49(5), 539-555.

WBB (2019). Bangladesh at a glance. The World Bank in Bangladesh (WBB). $<$ https://www.worldbank.org/en/country/bangladesh> (Accessed 20 September 2020). 
World Bank (2001). Involuntary Resettlement Sourcebook. Planning and implementation in development projects.<http://documents1.worldbank.org/curated/en/206671468782373680/pdf/301180v110PAPE1e ttlement0sourcebook.pdf $>$ (Accessed 20 September 2020).

(C) 2021 the Authors. Journal of Engineering Science published by Faculty of Civil Engineering, Khulna University of Engineering \& Technology. This is an open access article under the terms of the Creative Commons AttributionNonCommercial-NoDerivatives License, which permits use and distribution in any medium, provided the original work is properly cited, the use is non-commercial and no Modifications or adaptations are made. 